\title{
Sustainable Governance to Improve the Performance of SOEs Bank Listed on Indonesian Stock Exchange that are Classified as LQ45
}

\author{
Dahlia Banjarnahor ${ }^{\text {a1 }}$, Mochamad Muslih ${ }^{\text {b2 }}$ \\ ${ }^{1,2}$ STIE Tri Bhakti, Indonesia \\ Email : ${ }^{1}$ dahliaemamarintan@gmail.com, ${ }^{2}$ mochamadmuslih@ stietribhakti.ac.id \\ Corresponding Author
}

\section{ARTICLE INFO}

Article history

Received 2020-08-31

Revised 2020-09-12

Accepted 2020-09-19

Keywords

Governance, Compensation, Size,

Audit committee, Performance

\begin{abstract}
Corporate governance is useful for improving company performance. Company performance can be in the form of financial performance or nonfinancial performance. In this digital era, the role of governance is very important. One of the elements of governance is information technology governance. The purpose of this research is to study the effect of corporate governance on the performance of the State-Owned Banks listed on the Indonesia Stock Exchange which is classified as $L Q 45$. The research method is quantitative method. The 3 (three) governance variables used in this study are commissioners compensation, board size, and audit committee size. The population is state-owned banking sector companies listed on the Indonesia Stock Exchange classified as LQ 45.
\end{abstract}

\section{INTRODUCTION}

The success of a company is determined by its performance. Performance is the result achieved by workers in their work according to certain criteria that apply to a job. In accordance with the opinion of Robbins (2001) states that performance is an outcome achieved by workers in their work according to certain criteria that apply to a job. Employee and management performance is very important in achieving organizational goals.

Humans always play an important and dominant role in every organization. No matter how good the program made by the company, it will be difficult to run without the active role of employees owned by the company. Therefore, companies need to pay attention to the factors in improving employee performance. Such as providing compensation to employees in the hope of improving performance. Because the attention of an organization or company towards giving fair compensation, it can improve employee performance. If the compensation provided is not balanced, the work performance or job satisfaction of the employees will decrease. If employees perceive their compensation to be inadequate, it will have an impact on performance, work culture and job satisfaction can decrease (Robbins, 2006: 146). Providing appropriate compensation will have a very positive effect on employees. Because it cannot be assumed that the compensation will be the main objective for some of the employees who work in a company.

Compensation is everything that employees receive in return for their services. Compensation is a contribution received by employees in accordance with the work that has been done or carried out.

In banking companies, achievement can be seen from the way employees improve their performance pthere is such a company. One indicator of the progress of a country can be seen from the progress of its capital market. At this time the role of the capital market is very important in providing a source of financing for companies. The sector that requires funding from the capital market is banking. At this time the banking industry plays a very important role because almost all sectors related to financial activities will always require bank services. 
The bank's financial performance is an illustration of the success achieved by the bank in its operational activities. The performance of a bank can be assessed by analyzing its financial statements.Based on these financial reports, the financial ratios can be calculated to assess the soundness of the bank. The analysis of these financial ratios enables the management to identify the success of the bank in conducting its operational activities. Financial ratio analysis can also assess the financial performance of a bank.

In improving company performance, the role of commissioners and audit committees is needed in determining the continuity of a company, which is proxied by ROA. This means that any increase in the size of the board of commissioners will decrease the value of the bank's ROA. If the board of commissioners has decreased, the ROA of the bank will increase.

The board of commissioners has a function, namely to ensure that the company's operations run in accordance with company policy. Meanwhile, the function of the audit committee is to ensure that dayto-day operations run in accordance with the policies set by the company.In accordance with the regulations issued by the Financial Services Authority Number 55 / POJK.04 / 2015, dated 23 December 2015 concerning the Formation and Guidelines for the Implementation of the Audit Committee's Work, the purpose of establishing the Audit Committee is to ensure the implementation of corporate governance. The implementation of GCG in a company is very necessary because it is considered important in order to increase the value of a company.

The Board of Commissioners forms the Audit Committee as a support in carrying out its duties and obligations. The determination of the establishment of the Audit Committee is carried out through a Decree of the Board of Commissioners and is chaired by an Independent Commissioner appointed by the Board of Commissioners.

Based on the above background, the researcher tries to conduct research further on 'The Effect of Commissioner Compensation, Commissioner Size and Audit Committee Size on the Performance of Companies Listed on the Indonesia Stock Exchange (BEI) 2013-2018

Based on the discussion above, the research problem can be formulated as follows:

1. Does the commissioner's compensation affect the company's performance?

2. Does the size of the board of commissioners affect the company's performance?

3. Does the size of the audit committee affect the company's performance?

The objectives of this study are to:

1. Studying the effect of commissioners compensation on company performance.

2. Studying the effect of board size on company performance.

3. Studying the effect of audit committee size on company performance.

The theory tested in this study is agency theory or agency theory. Agency theory regulates the relationship between owner and manager. The relationship between owner and manager must be structured so that the manager will decide and act in the interests of the owner or shareholders. Jensen and Meckling (1976) stated in the results of their research that shareholders can ensure that managers as agents make optimal decisions only if appropriate incentives are given to managers and proper monitoring of managers is carried out. Jensen and Meckling in Haryono (2012) state that organization is seen as a nexus and a set of contracts among production factors. The bigger the organization, the farther the relationship between the principal and the manager as the agent of the company. Thus, arrangements are needed for the principal relationship as the owner of the company with management as the agent of the company. Scott (2015, p. 358) defines agency theory as a branch of game theory that studies contract design to motivate rational agents to act on behalf of the principal, if the agent's interests are different, it will cause conflict with the principal. In this research will be studied how the influence of management compensation as a company agent on company performance. if the agent's interests are different, it will 
cause conflict with the principal. In this research will be studied how the influence of management compensation as a company agent on company performance. if the agent's interests are different, it will cause conflict with the principal. In this research, it will be studied how the influence of management compensation as a company agent on company performance.

Performance is the achievement of an employee in completing the tasks assigned to him within a certain period of time in a company. So that the performance of quality employees is needed to be able to provide maximum contribution to the company. Performance is an optimal achievement in accordance with one's potential, which is something that is often the concern of organizational leaders (Robbins 2006: 121). Performance is the result of work in quality and quantity achieved by an employee in carrying out his duties in accordance with the responsibilities given to him (Anwar PrabuMangkunegara (2009: 67).

ROA is the result of a comparison between net income (earning after tax) companies with total assets owned by the company. ROA is a type of profitability ratio, which measurement is used to assess how well a company is performing in generating net income and the utilization of its assets. Kasmir (2014: 201) argues that ROA is a ratio of employees that shows returns on users of company assets. Fahmi (2014: 186) defines that ROA is a measuring tool used to assess the extent to which investment capital is invested and is able to generate profits in accordance with the investment capital invested and in accordance with expectations.

ROA in a company can be calculated using the following formula:

$\mathrm{ROA}=$ (net profit after tax / total company assets) $\mathrm{x} 100 \%$.

Corporate governanceis a set of rules governing the relationship between shareholders, managers (managers), creditors, government, employees and other internal and external stakeholders relating to their rights and obligations, or in other words a system that regulates and controls the company. .

Good corporate governance (FCCG) in Effendi's book (2017: 1) defines corporate governance as a process and structure used to direct and manage business and company activities to the level of business growth and corporate accountability. Good corporate governance (FCGI) in Effendi's book (2017: 2) defines god corporate governance as a set of regulations governing the relationship between shareholders, company managers, creditors, government, employees, and other internal and external stakeholders who relating to their rights and obligations or in other words a system that controls the company.

One of the objectives of governance according to law no. 40 of 2007 is to maximize the value of BUMN by enhancing the principles of openness, accountability, trustworthiness, responsibility, and fairness so that companies have strong competitiveness, both nationally and internationally.

In the Financial Services Authority (OJK) Regulation Number 55 / POJK.03 / 2016 concerning the Implementation of Commercial Bank Governance, it is stated that good corporate governance is one of the methods of bank processing, which applies the principles of GCG, namely transparency, accountability. (accountability), responsibility, independent (independency), and fairness (fairness).

In improving the welfare of employees or employees, an organization must be effective and fair in distributing compensation in accordance with the workload received by employees. Compensation is any direct or indirect reward that affects the level of employee performance. Therefore, giving compensation to employees needs special attention from agency management so that employee motivation can be maintained and employee performance can increase and employee loyalty to the company will increase. This certainly has a positive impact on the performance and achievement of company goals. 
HandokoSeptawan (2014: 5) states that compensation is everything that workers receive as remuneration for their work. According to RivaiSeptawan (2014: 5) states that compensation is something that employees receive as a substitute for their service contribution to the company. According to Septawan (2014: 5) compensation is a reward for services or remuneration provided by the company to its workers, because these workers have contributed energy and thoughts for the progress of the company to achieve predetermined goals.

Based on the above understanding, it can be concluded that compensation is a relationship or interaction between employees and organizations. Which is in the form of feedback from services or personnel provided by employees and awards from the organization in the form of wages or facilities and abilities that have been given during a certain period of time as a contribution to the achievement of organizational goals.

The purpose of compensation is to increase employee motivation at work. A good compensation system will ensure fairness between employees and the organization. Each employee will be rewarded according to work goals, functions and achievements.

According to Hasibuan (2013: 128) the factors that influence compensation are the supply and demand for labor, the ability and willingness of companies, labor unions and employee organizations, types and nature of work, government with laws and regulations, cost of living, position employee positions, education and work experience, and national economic conditions.

According to paragraph 6 of Law Number 40 of 2007 concerning limited liability companies, the board of commissioners is a company organ that is tasked with conducting general supervision according to the articles of association and providing advice to the board of directors. KNKG (2006) defines the board of commissioners as part of a company organ that is collectively tasked and responsible for supervising and providing advice to directors and ensuring that the company implements GCG. However, the board of commissioners may not participate in making operational decisions.

This definition shows that the board of commissioners is a part of a company organ whose job is to supervise, provide directions or directions to company managers, and ensure that the company implements good corporate governance.

In Law, Undang-Undang No. 40 of 2007 concerning Limited Liability Companies (UU PT) in Effendi's book (2017: 35) which regulates the duties and functions of the commissioners in the following articles in article 1 point (2) states that the board of commissioners is one of the organs of the company, apart from the General Meeting of Shareholders and directors. Point 6 of the article explains that the board of commissioners is a corporate organ that is tasked with conducting general and / or specific supervision in accordance with the articles of association and providing advice to the board of directors.

The audit committee is a committee or body formed by the board of commissioners which aims to assist in conducting checks, examinations and research which are considered important in carrying out the duties and functions of the board of directors in the processing of a listed company.

The task of the Audit Committee according to the SOE ministerial decree No: Kep-117 / M-MBU / 2002 is to provide an assessment of the activities carried out and an assessment of the results of the audit carried out by the internal control unit and the external auditor so that implementation and reporting that do not meet standards can be prevented; provide recommendations for the improvement of the company's management control system and control; ensure the availability of satisfactory review procedures, especially for information issued by BUMN; carry out identification of matters requiring the attention of the board of commissioners; and fulfill other duties and obligations given by the board of commissioners, provided that these obligations are still within the scope based on the provisions of the prevailing laws and regulations. 
The authority of the Audit Committee is to fully access all data, documents and information, employees, funds, assets, and resources needed or used; conduct direct communication with employees, including directors and parties who carry out internal audit functions, risk management and accountants related to the duties and responsibilities of the audit committee; if necessary, with the approval of the board of commissioners, the audit committee can employ other parties or experts to assist the audit committee in carrying out the duties of the audit committee; and exercise other powers assigned by the Board of Commissioners.

\section{Hypothesis Development}

\section{The effect of commissioners compensation on company performance}

Commissioner compensation aims to compensate the services provided by the commissioners based on their expertise. The Board of Commissioners is in charge of directing and overseeing the company's operations. For his services to direct and supervise the running of the company, the commissioners are given certain compensation. Logically, the greater the compensation given to the commissioners, the enthusiasm and motivation will increase and will boost their performance.

Previous research results have shown the benefits of commissioners' compensation on company performance. Samudra (2014) concluded from the results of his research that direct financial compensation has a strong relationship with employee performance. Suwati (2013) states that compensation has a partial effect on employee performance. Yusnita (2014) concluded from the results of his research that there was a real and positive relationship with employee compensation and performance. Suryana and Nuzula (2018) also obtained a similar conclusion from the results of their research, namely that there is a significant effect of executive compensation on return on assets.

Based on the discussion above, the hypothesis is as follows:

H1: Compensation for commissioners has a positive effect on company performance.

\section{The effect of board size on company performance}

The size of the Board of Commissioners means the number of members of the Board of Commissioners. The Board of Commissioners' organs consist of the President Commissioner, Commissioner, Independent Commissioner, Committees and the Secretary of the Board of Commissioners. The President Commissioner represents the majority shareholder. Commissioners represent minority shareholders. Independent commissioners do not come from majority or minority shareholders. The committee consists of a chairman and members. The bigger the size of the board of commissioners, the greater the ability of the board of commissioners to direct and supervise the running of the company.

The results of previous research have also shown the influence of the size of the Board of Commissioners on company performance. Suryana and Nuzula (2018) concluded from the results of their research that the size of the Board of Commissioners has an effect on company performance.

Based on the discussion above, the hypothesis is:

H2: The size of the Board of Commissioners has a positive effect on company performance.

\section{The effect of the size of the Audit Committee on company performance}

The Audit Committee is a supporting organ for the Board of Commissioners. Its job is to assist the Board of Commissioners in directing and controlling the company's operations. The Audit Committee consists of a chairman and members. So the minimum number is 2 (two) people. Financial Services Authority Regulation Number 55 of 2017 even stipulates that the number of audit committees is at least 3 (three) people. The more the number of the Audit Committee, the more the Committee's capacity to 
analyze the company's operations. Thus, the greater the number of Audit Committees, the more they will encourage company performance.

Previous research results have also supported the effect of audit opinion on company performance.Riniati (2015) concludes from the results of her research that the Audit Committee has a significant effect on company performance.

Based on the discussion above, the hypothesis is as follows:

H3: The size of the Audit Committee has a positive effect on company performance.

\section{Research Framework}

Based on the development of the hypothesis described above, the research framework can be described as follows:



\section{RESULTS AND DISCUSSION}

\section{Research Results}

The unit of analysis is BUMN Banking listed on the Indonesia Stock Exchange which is classified as LQ 45.

The normality test shows the results as in Figure 1 below.

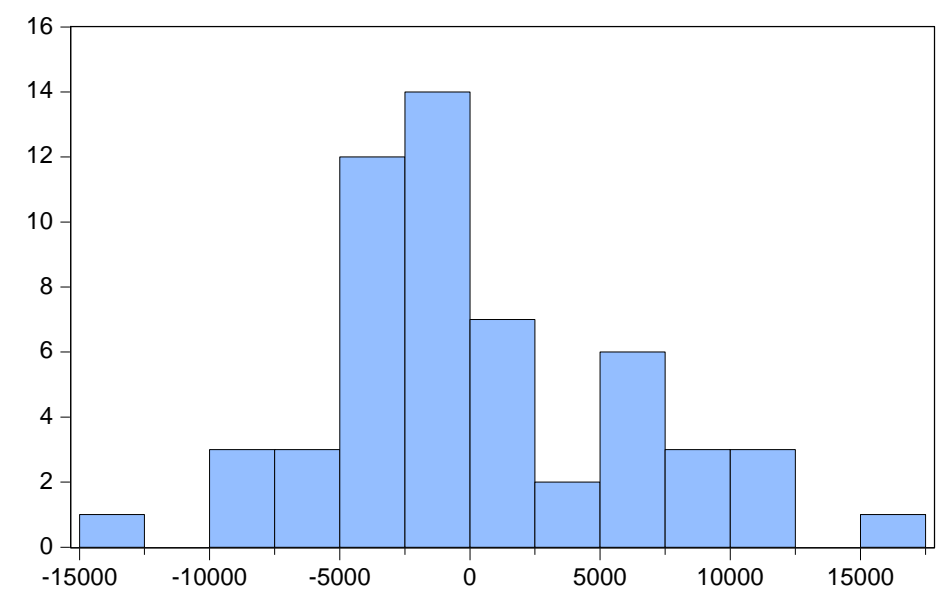

\begin{tabular}{|c|c|}
\hline \multicolumn{2}{|c|}{$\begin{array}{l}\text { Series: Residuals } \\
\text { Sample } 155 \\
\text { Observations } 55\end{array}$} \\
\hline Mean & $9.26 \mathrm{e}-13$ \\
\hline Median & -825.0585 \\
\hline Maximum & 15013.45 \\
\hline Minimum & -14527.66 \\
\hline Std. Dev. & 5888.902 \\
\hline Skewness & 0.357898 \\
\hline Kurtosis & 3.051191 \\
\hline Jarqu & \\
\hline Probability & 0.55427 \\
\hline
\end{tabular}

Figure 1. Normality Test Results 


\section{E ISSN 2621-749X}

In Figure 1 above, it can be seen that the Jarqua Berra indicator is $1.18<2$. Research data is normally distributed. Heteroscedasticity test, multicollinearity test and autocorrelation test have been carried out. There is no heteroscedasticity, multicollinearity, and autocorrelation. The research data has passed the classical assumption test.

The regression test carried out with the Eviews 9 program shows the following results:

Dependent Variable: Y

Method: Least Squares

Date: 07/19/19 Time: 07:51

Sample: 155

Included observations: 55

\begin{tabular}{crcrr}
\hline \hline Variable & Coefficient & Std. Error & t-Statistic & Prob. \\
\hline \hline C & -18696.07 & 4328,318 & -4.319477 & 0.0001 \\
X1 & 0.034241 & 0.010462 & 3.272923 & 0.0019 \\
X2 & 3494,740 & 607.0623 & 5.756806 & 0.0000 \\
X3 & 553.7270 & 683.4219 & 0.810227 & 0.4216 \\
\hline \hline R-squared & 0.582846 & Mean dependent var & \multirow{2}{*}{9265,400} \\
Adjusted R-squared & 0.558308 & SD dependent var & 9117,720 \\
SE of regression & 6059,631 & Akaike info criterion & 20.32663 \\
Sum squared resid & $1.87 \mathrm{E}+09$ & Schwarz criterion & 20.47262 \\
Log likelihood & -554.9824 & Hannan-Quinn criter. & 20.38309 \\
F-statistic & 23,75235 & Durbin-Watson stat & 0.978014 \\
Prob (F-statistic) & 0.000000 & & \\
\hline \hline
\end{tabular}

Figure 2. Regression Test Results

From the regression test above, it can be seen that the coefficient of variable $\mathrm{X} 1$ is positive, with a prob $0.00<0.05$. Significant. This means that compensation for commissioners has an effect on company performance. The coefficient of variable X2 is positive, with a prob $0.00<0.05$. Significant. This means that the size of the commissioners has an effect on company performance. The coefficient of the variable $\mathrm{X} 3$ is positive, with a probability of $0.42<0.05$. Not significant. This means that the size of the Audit Committee has no significant effect on company performance.

\section{Discussion}

From the research results above, it can be seen that the compensation for commissioners has a significant positive effect on company performance. This means that an increase in commissioners' compensation will increase the capacity and motivation of commissioners to improve company performance. The results of this study are in line with research by Samudra (2014), Suwati (2013), Yusnita (2014), JyotikaBahl (2015), and Suryana and Nuzula (2018).

The size of the commissioners has a significant effect on company performance. This means that an increase in the number of board of commissioners personnel will increase the capacity of the board of commissioners to conduct direction and monitoring of management activities. The board of commissioners will have more time to evaluate the realization of company planning, evaluate corporate 
risk management, evaluate company information technology, evaluate other management aspects, and direct the implementation of company operations. The results of this study are in line with the results of research by Suryana and Nuzula (2018).

The size of the audit committee has no significant effect on company performance. This means that increasing the number of audit committee personnel will not increase the capacity of the audit committee in conducting direction and monitoring of company operations. The results of this study are in line with the results of research by Widagdo and Chariri (2014).

\section{CONCLUSIONS AND SUGGESTIONS}

\section{Conclusion}

The purpose of this research is to study the effect of commissioners compensation on company performance, board size on company performance, and audit committee size on company performance.

The method used is a quantitative method. The data processing uses Eviews 9 software.

The population is state-owned banks listed on the Indonesian stock exchange which are classified as LQ 45. The sample is state-owned banks listed on the Indonesian stock exchange which are classified as LQ 45 from 2008 to 2018.

The results show that the compensation for commissioners has a significant effect on the performance of banking companies listed on the Indonesia Stock Exchange which are listed in LQ 45, the size of the commissioners has a significant effect on the performance of banking companies listed on the Indonesia Stock Exchange which are listed in LQ 45, and the size of the audit committee has no significant effect on the performance of banking companies listed on the Indonesia Stock Exchange which are listed in LQ 45.

\section{Suggestion}

Based on the suggestions above, the recommendations are as follows:

1. Creating a remuneration system for the Board of Commissioners so that it will further motivate the board of commissioners to improve its performance.

2. Improve the quality of the audit committee recruitment system so that the audit committee will be more qualified and skilled in carrying out its duties.

\section{REFERENCES}

Adestian, Yuda. (2015). Pengaruh Dewan Komisaris, Dewan Direksi, Dewan KomisarisIndependen, Komite Audit dan Ukuran Perusahaan pada Kinerja Perusahaan Perbankan.UDINUS. Semarang.

Buachoom, Wonlop. (2017). Simultaneous Relationship Between Peformance and Kompensasi Eksekutif of Thai NonFinancial Firms. Asian Review of Accounting, Vol. 25 Issue: 3, pp. 404-423.

Bahl, Jyotika. (2015) .Dampak Kompensasi Karyawan terhadap Kinerja Perusahaan. Jurnal Internasional Bisnis, 1 Februari 2015.

Buachoom, Wonlop. 2017. Simultaneous Relationship BetweenPeformance and KompensasiEksekutif of Thai NonFinancial Firms. Asian Review of Accounting, Vol. 25 Issue: 3, pp. 404-423.

Badan Pengawas Pasar Modal. (2004). Kep-29/PM/2004 tentang Komisaris dan Komite Audit dalam Pelaksanaan Corporate Governance. 


\section{E ISSN 2621-749X}

Brigham, Eugene F., Mivhael, Ehrhardt C. (2005).Financial Management Theory and Practice.International Student Edition, South Western.

Dewi,Aminar Sutra, Sari, Desfriana, dan Abaharis, Henryanto.(2018). Pengaruh Karateristik Dewan Komisaris terhadap Kinerja Perusahaan Manufaktur di Bursa Efek Indonesia JurnalBenefita, 3(3) : $445-454$.

Effendi M.A .(2017). The Power Of Good Corporate Governance: TeoridanImplementasi. Edisi 2, Cetakanke -2. Jakarta; SalembaEmpat

Kasmir. 2014. Analisis Laporan Keuangan, EdisiSatu, Cetakan Ketujuh. Jakarta: Raja Grafindo Persada.

Makhrus, Mohammad. 2013. Pengaruh Komite Audit Terhadap Kinerja Perusahaan Melalui Manajemen Laba Sebagai Variabel Intervening. Jurnal Akuntansi dan keuangan Islam Sekolah Tinggi Ekonomi Islam SEBI.

Mangkunegara, A.A Anwar Prabu .2009.Manajemen Sumber Daya Manusia. Bandung :PT.RemajaRosdakarya.

Menteri Negara Badan Usaha Milik Negara (BUMN) Republik Indonesia. 2011. PeraturanMenteri BUMN Nomor: PER-01/MBU/2011tentangPenerapan Tata KelolaPerusahaan yang Baik (GCG) pada BUMN.

Muharam, H. 2012. Kompensasi Chief Executive Officer (CEO) dan Kinerja Perusahaan. Jurnal Studi Manajemen Organisasi, vol. 1, no. 2, pp. 9-15, Nov.

OtoritasJasaKeuangan. 2015. Peraturan OtoritasJasaKeuanganNomor : 55/POJK.04/2015, tanggal 23 Desember 2015, tentang Pembentukan dan PedomanPelaksanaanKerjaKomite Audit.

Panky, Sukandar \& Raharja.(2014). PengaruhUkuran Dewan Direksi dan Dewan Komisaris serta Ukuran Perusahaan terhadap Kinerja Keuangan Perusahaan (Studi Empiris pada Perusahaan Manufaktur Sektor Consumer Good yang terdaftar di BEI tahun 2010 - 2012).Volume 3, Nomor 3, halaman 17. Fakultas Ekonomi dan Bisnis. Universitas Diponegoro Semarang.

Perdana,Ramadhan Sukma, Raharja. (2014) .AnalisisPengaruh Corporate Governance TerhadapNilai Perusahaan.Diponegoro Journal Of Accounting Semarang.

Riniati, K. (2015). Pengaruh Komisaris Independen dan Komite Audit terhadap Kinerja Perusahaan yang terdaftar di BEI 2011-2013.Fakultas Ekonomi, Universitas Negeri Yogyakarta.

Robbins, Stephen P. 2001. Perilaku Organisasi: Konsep, Kontroversi, Aplikasi, Jilid 1, Edisi 8.Prenhallindo, Jakarta.

Riniati, Kuslinah. (2013). Pengaruh Komisaris Independen Dan Komite Audit Terhadap Kinerja Perusahaan (Perusahaan Yang Terdaftar Di BEI 2011- 2013).Jurnal Akuntansi UNY Vol.1, No. 1 P $1-17$.

Rahmawati, Inge Andhitya., Brady Rikumahu., Vaya Juliana Dillak. (2017). Pengaruh Dewan Direksi, Dewan Komisaris, Komite Audit dan Corporate Social Responsibility terhadap Kinerja Keuangan Perusahaan. Jurnal Akuntansi \& Ekonomi FE.UN. PGRI Kediri Vol. 2 No. 2, September 2017 
S.P, Hasibuan ,Malayu. 2013. Manajemen Sumber Daya Manusia. Jakarta: PT. Bumi Aksara. SamodraWibawadkk.

Sugiyono. (2013). Metode Penelitian Kuantitatif, Kualitatif dan R\&D. Bandung: Alfabeta CV.

Widagdo, Kresno, Dominikus Octavianto, Chariri, Anis. (2014). Pengaruh Good Corporate Governance terhadap Kinerja Perusahaan. e-Journal Accounting Universitas Diponegoro, Semarang. Vol. 3, No. 3, Hal: 1.

Yuliani, Rifa, Nurul. (2018). Pengaruh Komisaris Independen, Komite Audit, dan Rasio Leverage Terhadap Kinerja Keuangan Pada Perusahaan Farmasi Yang Terdaftar Di BEI Tahun 20122016. Fakultas Ekonomi. 